Article

\title{
Beta-Cyclodextrin-Assisted Synthesis of Silver Nanoparticle Network and Its Application in a Hydrogen Generation Reaction
}

\author{
Clay Huff, Julia M. Long and Tarek M. Abdel-Fattah *D \\ Applied Research Center at Thomas Jefferson National Accelerator Facility and Department of Molecular \\ Biology and Chemistry at Christopher Newport University, Newport News, VA 23606, USA; \\ clay.huff.12@cnu.edu (C.H.); julia.long.15@cnu.edu (J.M.L.) \\ * Correspondence: fattah@cnu.edu
}

Received: 6 August 2020; Accepted: 1 September 2020; Published: 3 September 2020

check for updates

\begin{abstract}
The unsustainable nature of carbon-based fuels has prompted scientists and engineers to investigate alternative sources of energy. Silver nanoparticle networks (AgNPNs) were synthesized using beta-cyclodextrin for applications in hydrogen evolution reactions from sodium borohydride $\left(\mathrm{NaBH}_{4}\right)$. The identities of the AgNPNs were confirmed using ultraviolet-visible spectroscopy, X-ray diffraction, and Transmission electron microscopy (TEM). The catalytic activity of the hydrogen evolution reactions was measured using a gravimetric water displacement system. The data collected show an increase in the efficiency of the hydrogen generation reaction with the addition of AgNPN. The silver nanoparticle network catalyst performed best at $22{ }^{\circ} \mathrm{C}$ with an increased concentration of $\mathrm{NaBH}_{4}$ producing hydrogen at a rate of $0.961 \mathrm{~mL} \cdot \mathrm{min}^{-1} \cdot \mathrm{mL}_{\mathrm{cat}}{ }^{-1}$. The activation energy was calculated to be $50.3 \mathrm{~kJ} / \mathrm{mol}$.
\end{abstract}

Keywords: hydrogen generation; silver nanoparticle networks; metal hydrides; hydrogen precursors

\section{Introduction}

The need for less harmful and more efficient fuel sources has grown rapidly in recent years. The economic and environmental consequences surrounding the use of traditional carbon-based fuels have reached unsustainable levels, prompting a new wave of research within the field of alternative fuels [1]. The burning and harvesting of gasoline are two main sources of excess carbon dioxide in Earth's atmosphere and a direct contributor to the global climate change issue [1-3]. Hydrogen has emerged as one of the more likely candidates for an environmentally friendly fuel alternative. However, there are problems associated with its viability as an alternative fuel. The main sources of hydrogen production today are steam reformation and electrolysis [4]. Steam reformation results in the release of carbon dioxide into the atmosphere because of a reaction between high-temperature steam and fossil fuels [4-6]. Electrolysis, though previously implemented successfully in small-scale systems, is limited on a large scale due to the cost of conducting water-splitting reactions [5]. In addition to the issues surrounding its production, the storage of hydrogen gas also poses a threat to its advancement as an alternative fuel. Hydrogen gas must be stored at high pressures, a requirement which in itself carries risks [7]. The search for a cleaner alternative to fossil fuels has led to the investment in studying new ways to harness hydrogen gas. One possible solution to producing hydrogen can be found in the reduction of hydrogen feedstocks, such as sodium borohydride $\left(\mathrm{NaBH}_{4}\right)$ catalyzed by nanoparticles [8].

The study of nanomaterials, specifically nanoparticles (NPs), and their applications have seen a rise in popularity in recent decades within the fields of chemistry, microbiology, medicine, textiles, electronics, and engineering [7,9-17]. Transition metal nanoparticles have been used to promote catalytic 
activity in chemical reactions, as an antimicrobial agent, and as an electrodepositing agent $[11,15,18-22]$. The properties of various metal nanoparticles differ from their bulk metal counterparts; the increased surface area allows for more efficient catalysis of reactions, as well as non-linear optical behavior and different electromagnetic properties [8,23].

Silver is a biologically non-essential metal with a minimal toxicity to humans. However, the extent of the deteriorating effects of silver on biological processes is not completely clear [12]. Studies indicate that the toxicity of silver ions to bacteria correlates with the concentration of silver in the environment, and in larger concentrations, silver nanoparticles can affect mitochondrial function as well as cell membrane permeability [12,24]. Silver nanoparticles (AgNPs) have also been studied in the fields of public health and medicine as an antimicrobial agent-for example, in filter coatings for water treatment and as part of wound dressings to improve recovery time in patients [25]. AgNPs have also been applied in catalysts in many reactions, such as organic reductions, hydrogen generation, and catalytic degradation of hazardous dyes [26-31]. AgNPs were also used in the catalytic oxidation of styrene, which demonstrates its flexibility for both oxidation and reduction reactions [32]. One important feature of nanoparticles, particularly AgNPs, is their high surface area-to-volume ratio. This allows for increased catalysis of reactions and more efficient transformation of reactants to products $[11,13,14,20-22]$. The aim of this research is to evaluate the ability of silver nanoparticle networks to catalyze a hydrolysis reaction of sodium borohydride and water in order to produce hydrogen gas for application as an alternative fuel system.

The goal of this study is to explore the catalytic activity of a network of Ag nanoparticles, and how it compares to previous studies of well-dispersed AgNPs over Multi-walled carbon nanotubes (MWCNTs) [15].

\section{Results and Discussion}

\subsection{Characterization of Catalyst}

Figure 1 shows a distribution of network silver nanoparticles within a colloidal solution. Particle size varied throughout the solution ranging from as small as $10 \mathrm{~nm}$ up to $100 \mathrm{~nm}$, as depicted in the histogram of 30 randomly selected nanoparticles in Figure 1. The average particle size was $36 \pm 21.5 \mathrm{~nm}$.

Beta-cyclodextrin is a commonly used capping agent and was used in the synthesis of the particles, with the goal of restricting this agglomeration. Its unique conformation, consisting of a small primary hydroxyl ring within a larger secondary hydroxyl ring (Figure 2), forms a conical shape, which is useful in exhibiting a level of control over the morphology of the particles by restricting their size and shape within the boundaries of the hydroxyl rings $[14,17,20]$.

The formation of networking was observed in Figure 1, which most likely occurred as a result of the high surface energy of the silver nanoparticle catalysts combined with hydrogen bonding contributed by the structure of beta-cyclodextrin (Figures 2 and 3) [11]. This interaction of silver nanoparticles and beta-cyclodextrin is depicted in Figure 3.

The UV-vis spectrum in Figure 4 shows the absorbance of silver nanoparticles in a colloidal solution. The peak at $\sim 400 \mathrm{~nm}$ is characteristic of an aqueous, capped silver nanoparticle suspension, and the shoulder at higher wavelengths $(\sim 550 \mathrm{~nm})$ is also commonly reported [26-29,31].

The XRD pattern depicted in Figure 5 reveals a characteristic diffraction pattern at $44.7^{\circ}$. This corresponds to the (200) plane of face-centered cubic silver [26,27,29,31,32]. The other lesser peaks present in the diffraction pattern are attributed to the carbon support. The XRD combined with the UV-vis spectrum indicates that the nanoparticles visualized under TEM microscopy are indeed composed of FCC silver. 


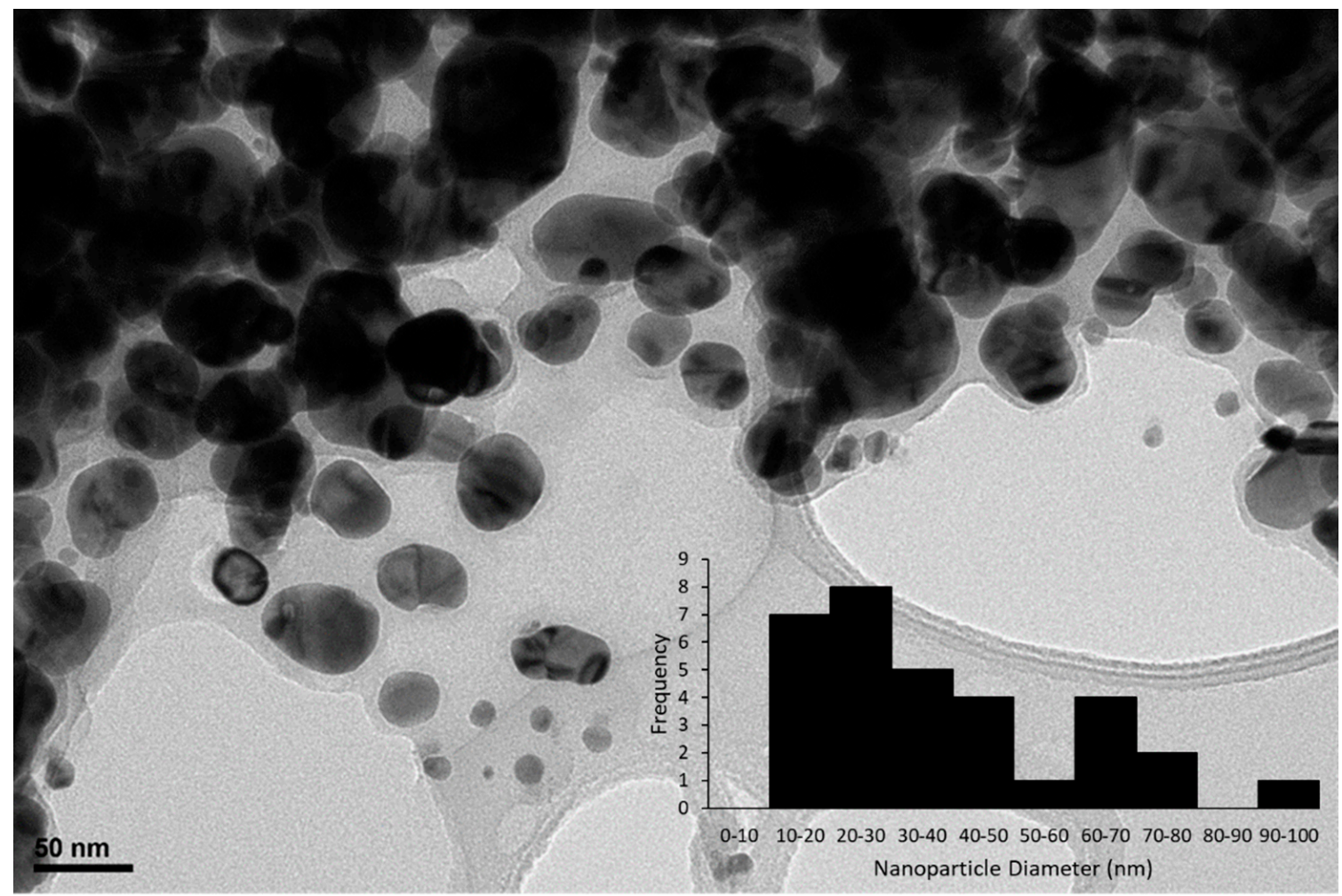

Figure 1. TEM micrographs of the Ag nanoparticle network. A silver nanoparticle network (AgNPN) is shown dispersed in solution and is depicted with a scale bar of $50 \mathrm{~nm}$ in the bottom left. A Histogram of nanoparticle diameter is inset in the bottom right. Average particle size is $36 \pm 21.5$ nanometers.

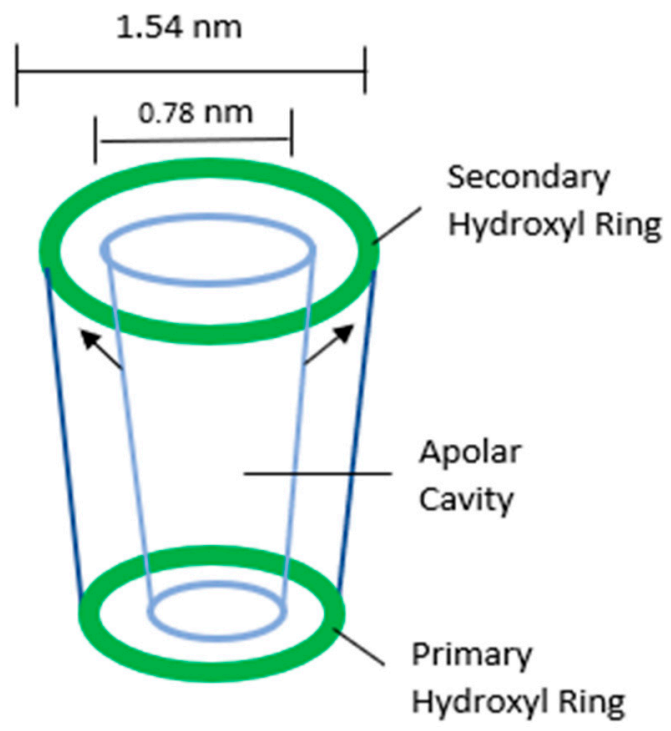

Figure 2. Beta-cyclodextrin depiction identifying the primary $(0.78 \mathrm{~nm})$ and secondary hydroxyl ring $(1.54 \mathrm{~nm})$ and inner a polar cavity. 


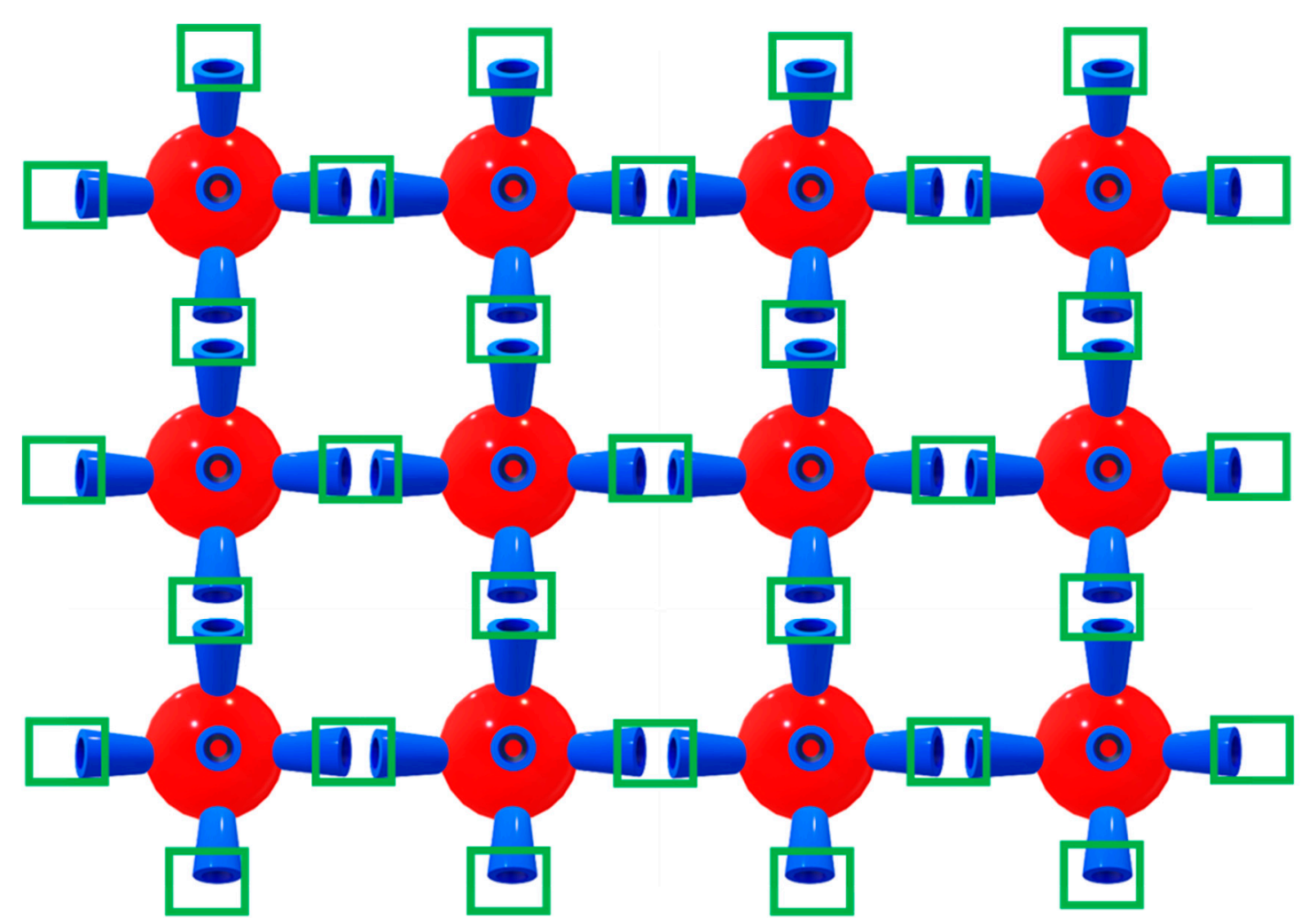

Figure 3. Visualization of the concept of networking of AgNPs due to the structure of beta-cyclodextrin. This can explain the morphology in the TEM image. Red, blue and green colors represent AgNPs, beta-cyclodextrin, and the linkers (hydroxyl groups of beta-cyclodextrin), respectively.

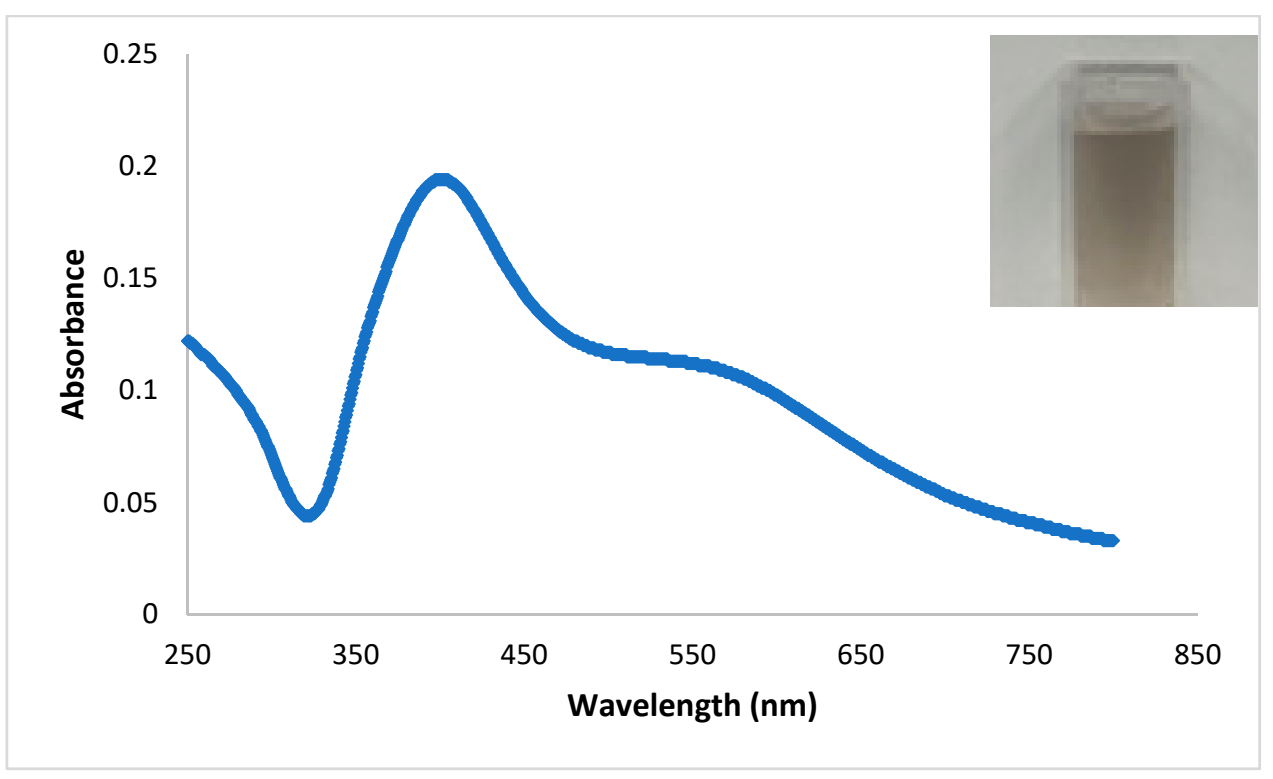

Figure 4. UV-vis spectrum of the Ag nanoparticles. Image in the upper righthand corner shows the Ag nanoparticle solution in the test cuvette. 


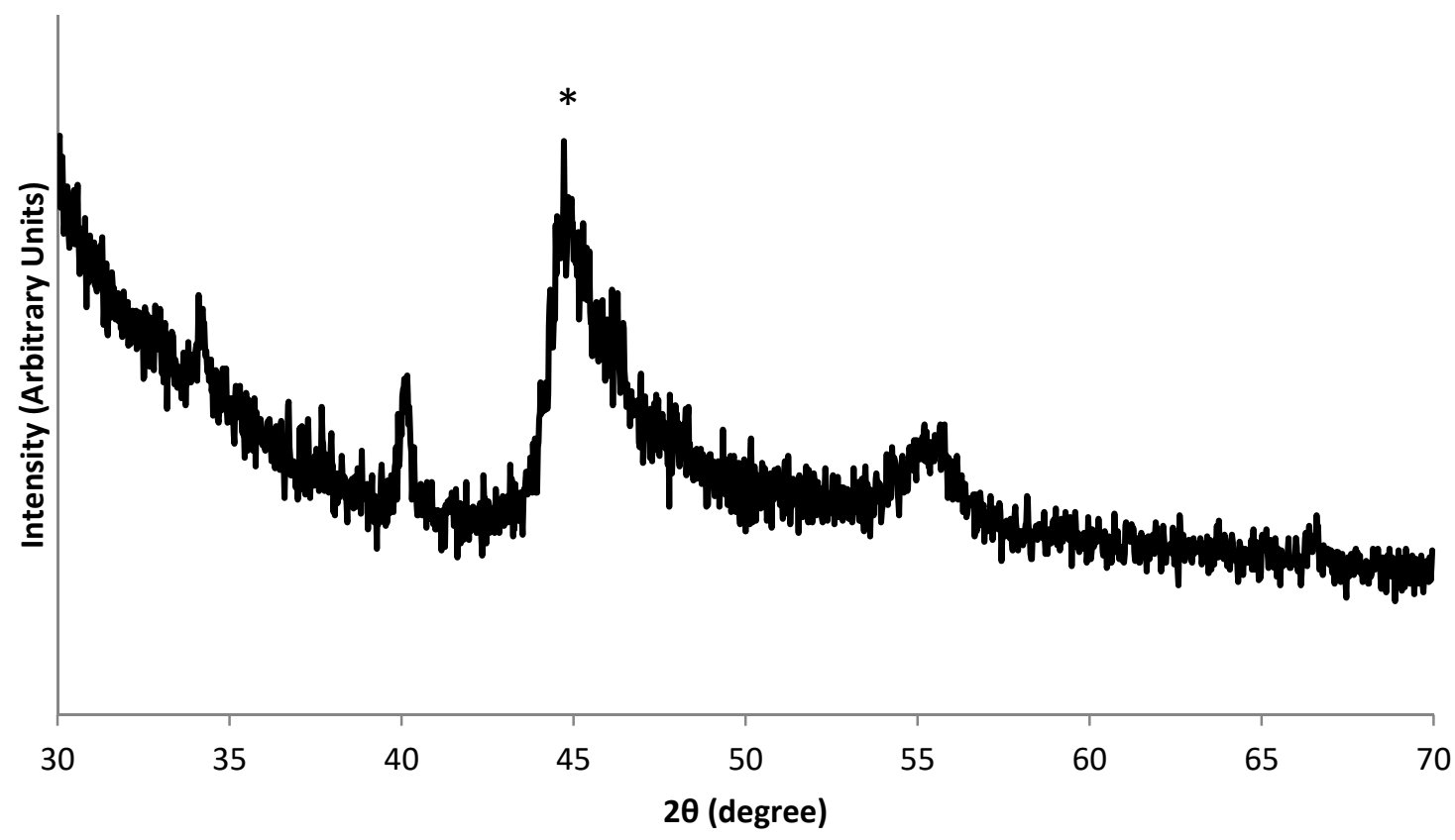

Figure 5. XRD patterns of the AgNPN supported over carbon. * The peak at $44.7^{\circ}$ is characteristic of the (200) plane of FCC silver.

\subsection{Catalytic Activity with Varied Concentrations of Reactant}

It was confirmed that the presence of silver nanoparticle networks in the reaction resulted in an increased production of hydrogen gas by a factor of $53 \%$ when compared to the uncatalyzed reaction (Figure 6). For the sodium borohydride-controlled trials, the highest rate at which hydrogen was produced was $0.961 \mathrm{~mL} \cdot \mathrm{min}^{-1} \cdot \mathrm{mL}_{\mathrm{cat}}{ }^{-1}$ for the increased concentration $(10.35 \mathrm{mM})$ of sodium borohydride. This trial outperformed the $6.35 \mathrm{mM}\left(0.217 \mathrm{~mL} \cdot \mathrm{min}^{-1} \cdot \mathrm{mL}_{\mathrm{cat}}{ }^{-1}\right)$ and $8.35 \mathrm{mM}$ $\left(0.878 \mathrm{~mL} \cdot \mathrm{min}^{-1} \cdot \mathrm{mL}_{\mathrm{cat}}{ }^{-1}\right)$ of sodium borohydride. Interestingly, the increase in performance between the 10.35 and $8.35 \mathrm{mM}$ trials was not as large as that between the 6.35 and $8.35 \mathrm{mM}$ trials. This suggests that the reaction was approaching saturation at the higher concentrations (8.35 and $10.35 \mathrm{mM})$. This increase in reaction rate associated with a higher concentration of sodium borohydride is expected and has been observed in various other catalytic studies [11].

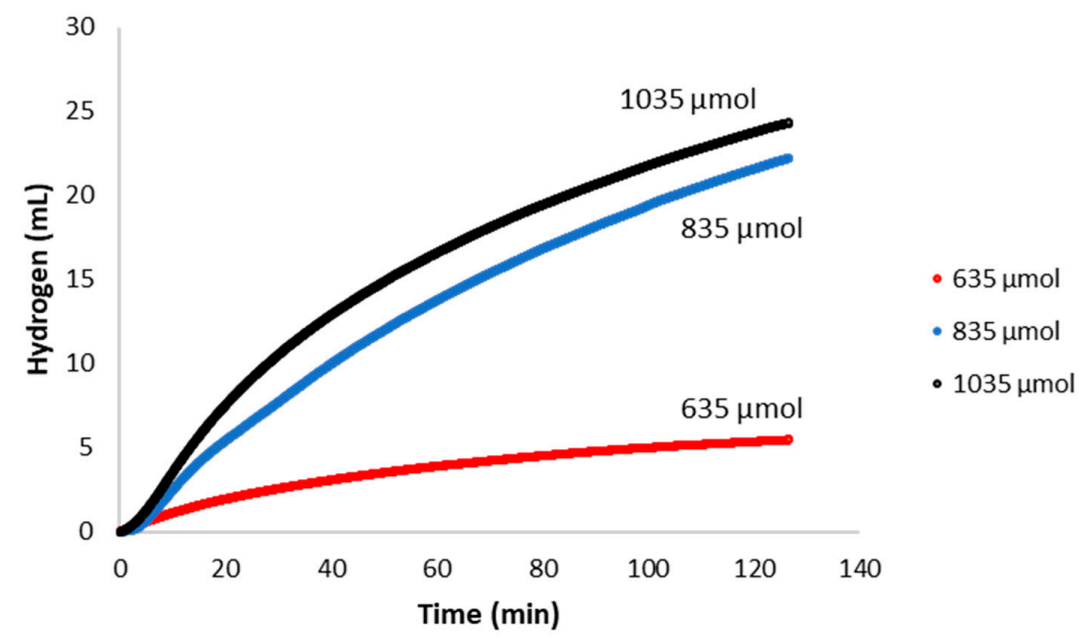

Figure 6. Comparison of the volume of hydrogen gas generated versus time by the AgNPN. The reactions were run at $835 \mu$ moles $(8.35 \mathrm{mM}), 1035 \mu$ moles $(10.35 \mathrm{mM})$, and $635 \mu$ moles $(6.35 \mathrm{mM})$ of $\mathrm{NaBH}_{4}$. 


\subsection{Catalytic Activity Under Varied $p H$ Conditions}

Adjusted $\mathrm{pH}$ trials revealed that a neutral $\mathrm{pH}$ environment is ideal for the hydrolysis reaction of sodium borohydride and water. The reaction produced hydrogen at the highest rate when subjected to a neutral $\mathrm{pH}$ of $7-0.878 \mathrm{~mL} \cdot \mathrm{min}^{-1} \cdot \mathrm{mL}_{\mathrm{cat}}{ }^{-1}$. This reaction outperformed the two other adjusted $\mathrm{pH}$ trials, at $\mathrm{pH} 6$ and $\mathrm{pH} 8$, which produced hydrogen at rates of 0.733 and $0.729 \mathrm{~mL} \cdot \mathrm{min}^{-1} \cdot \mathrm{mL}_{\mathrm{cat}}{ }^{-1}$, respectively (Figure 7). In the uncatalyzed reaction, hydroxyl ions $\left(\mathrm{OH}^{-}\right)$shift the equilibrium to favor the reactants, reducing $\mathrm{H}_{2}$ production $-\mathrm{H}^{+}$ions shift the equilibrium toward the products, as per Equation (1) [15]. This shift favors the formation of $\mathrm{BO}^{2-}$ ions in solution, which, in turn, causes the overall reaction to proceed faster at lower $\mathrm{pH}$.

$$
\mathrm{BH}_{4}^{-}+4 \mathrm{H}_{2} \mathrm{O} \rightarrow\left[\mathrm{B}(\mathrm{OH})_{4}\right]^{-}+4 \mathrm{H}_{2}
$$

Based on this theory, it can be concluded from Figure 7 that the catalyst is also susceptible to changes in $\mathrm{pH}$. In previous studies, similar results were observed using MWCNT-supported noble metal nanoparticles $[11,15,19]$.

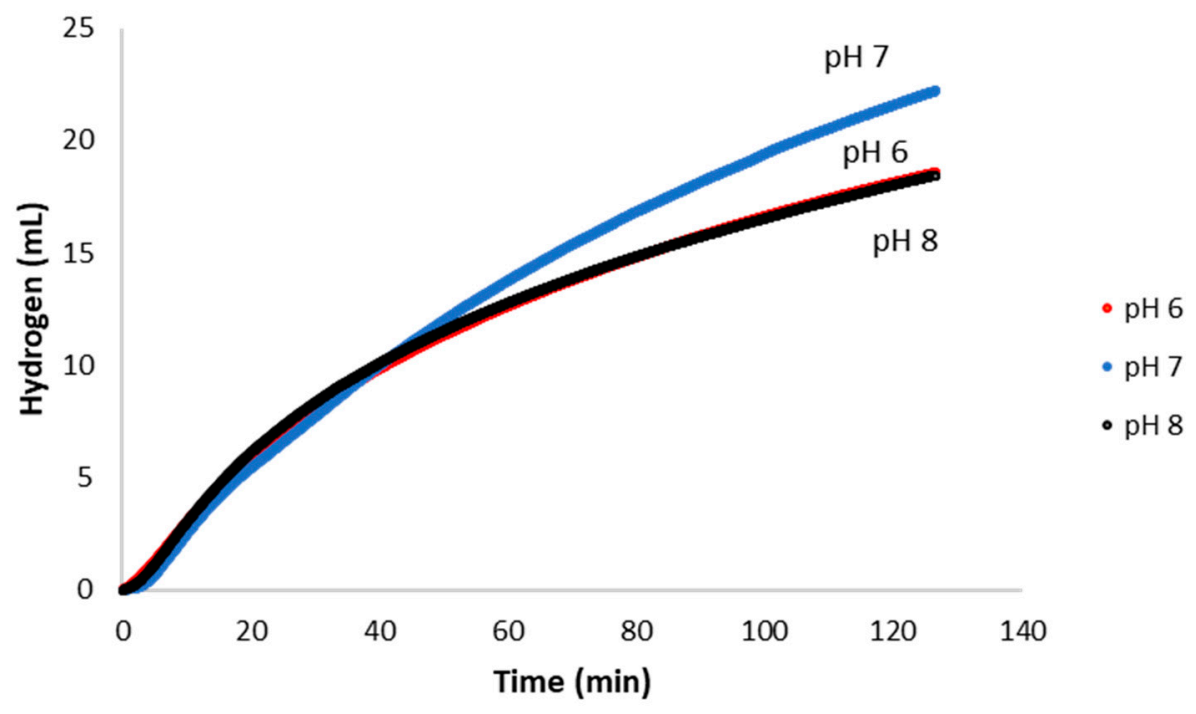

Figure 7. Comparison of the volume of hydrogen gas generated versus time. Volume of hydrogen gas generated by silver nanoparticle networks under adjusted $\mathrm{pH}$ conditions ( $\mathrm{pH}$ 6-8).

\subsection{Catalytic Activity at Varied Temperatures and Activation Energies}

Catalysis by the silver nanoparticle network under varying temperatures, as depicted in Figure 8 , revealed a non-linear trend. The highest reaction rate achieved was $0.878 \mathrm{~mL} \cdot \mathrm{min}^{-1} \cdot \mathrm{mL}_{\mathrm{cat}}{ }^{-1}$ at $22^{\circ} \mathrm{C}$. This significantly outperformed the other two rates achieved by the silver catalyst -0.586 and 0.086 $\mathrm{mL} \cdot \mathrm{min}^{-1} \cdot \mathrm{mL}_{\mathrm{cat}}{ }^{-1}$, at 30 and $0{ }^{\circ} \mathrm{C}$, respectively. The reduced reaction rate of the silver nanoparticles observed at $30^{\circ} \mathrm{C}$ can be attributed to an alteration in the capping effect of the beta-cyclodextrin. This effect may increase the ability of other negatively charged species in the reaction, such as nitrate and hydroxyl ions, to block access to the catalytically active sites, which has been reported to decrease catalytic activity [18]. The reaction's activation energy was determined based on the Arrhenius plot shown in Figure 9. The activation energy of the silver nanoparticle networks was calculated to be $50.3 \mathrm{~kJ} / \mathrm{mol}$. This compares competitively to literature values for activation energy generated by other known nanocatalysts (Table 1). The proposed mechanism of the AgNPN catalysis is depicted in Scheme 1. 


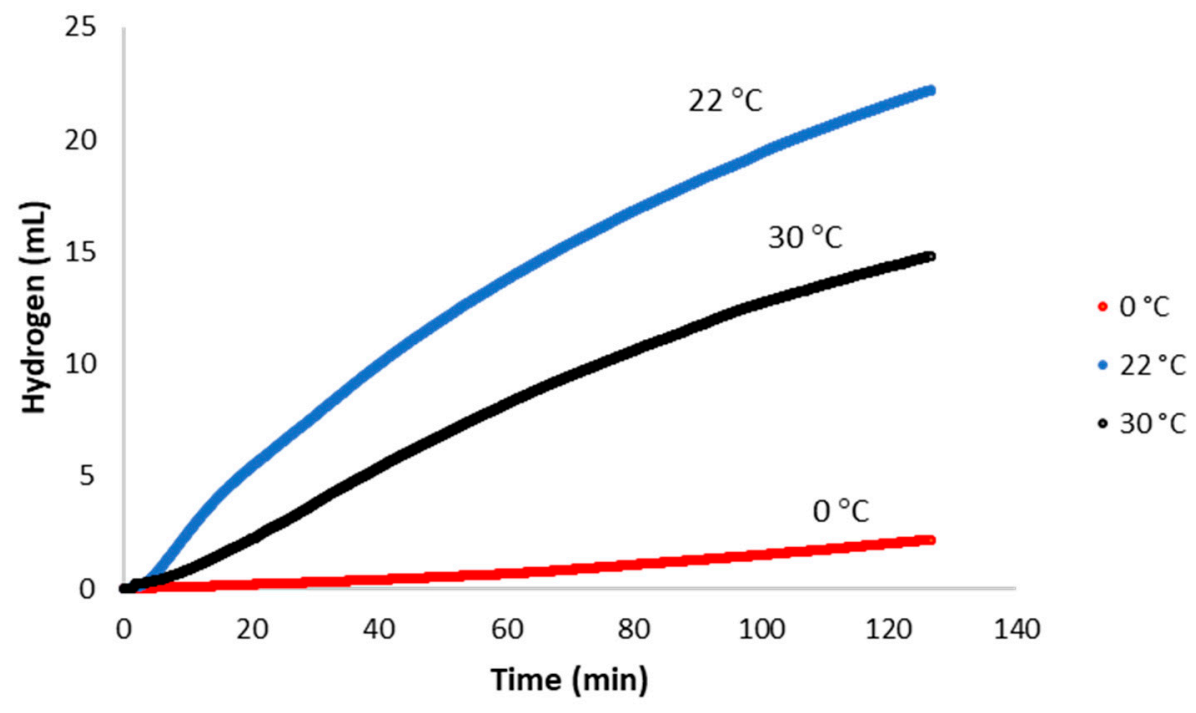

Figure 8. Volume of hydrogen gas produced over time generated by the hydrolysis reaction of sodium borohydride and water, as catalyzed by the produced silver nanoparticle network $\left(0,22\right.$, and $\left.30^{\circ} \mathrm{C}\right)$.

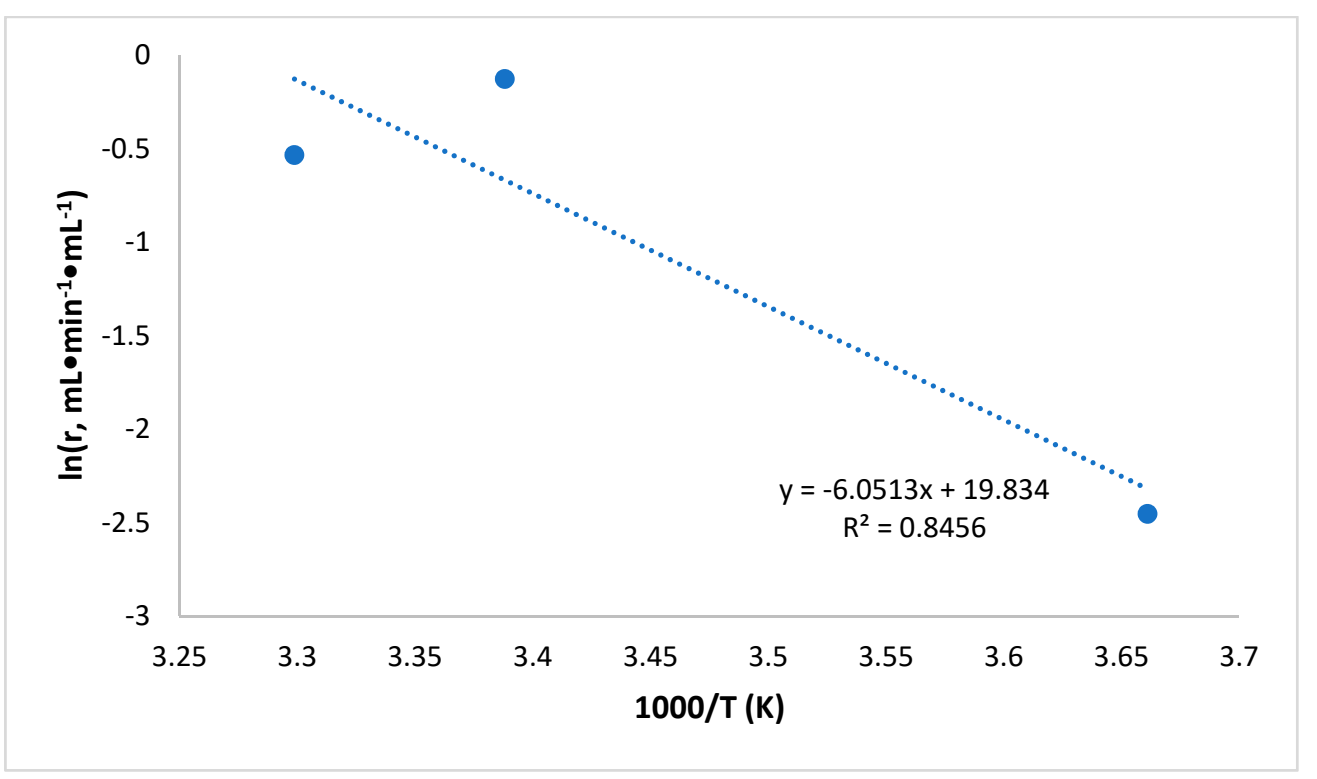

Figure 9. Arrhenius plot used to determine the activation energy of the silver nanoparticle network $(50.3 \mathrm{~kJ} / \mathrm{mol})$.

Table 1. Reported activation energies for $\mathrm{NaBH}_{4}$ hydrolysis by catalyst.

\begin{tabular}{cccc}
\hline Catalyst & $\mathbf{E}_{\mathbf{a}}(\mathbf{k J} / \mathbf{m o l})$ & Temperature $\left({ }^{\circ} \mathbf{C}\right)$ & Reference \\
\hline Co nanoparticles & 35.0 & $29-59$ & {$[33]$} \\
\hline ZrCo/C & 34.8 & $10-50$ & {$[34]$} \\
\hline Ru nanoclusters & 41.0 & $25-45$ & {$[21]$} \\
\hline Ni nanoclusters & 54.0 & $25-45$ & {$[22]$} \\
\hline $\mathrm{Pt} / \mathrm{C}$ & 45.0 & $15-75$ & {$[35]$} \\
\hline $\mathrm{Au} / \mathrm{MWCNTs}$ & 21.1 & $0-30$ & {$[11]$} \\
\hline $\mathrm{Pd} / \mathrm{MWCNTs}$ & 62.66 & $0-30$ & {$[19]$} \\
\hline $\mathrm{Ag} / \mathrm{MWCNTs}$ & 44.5 & $0-30$ & {$[15]$} \\
\hline $\mathrm{AgNPNs}$ & 50.3 & $0-30$ & This Work \\
\hline
\end{tabular}



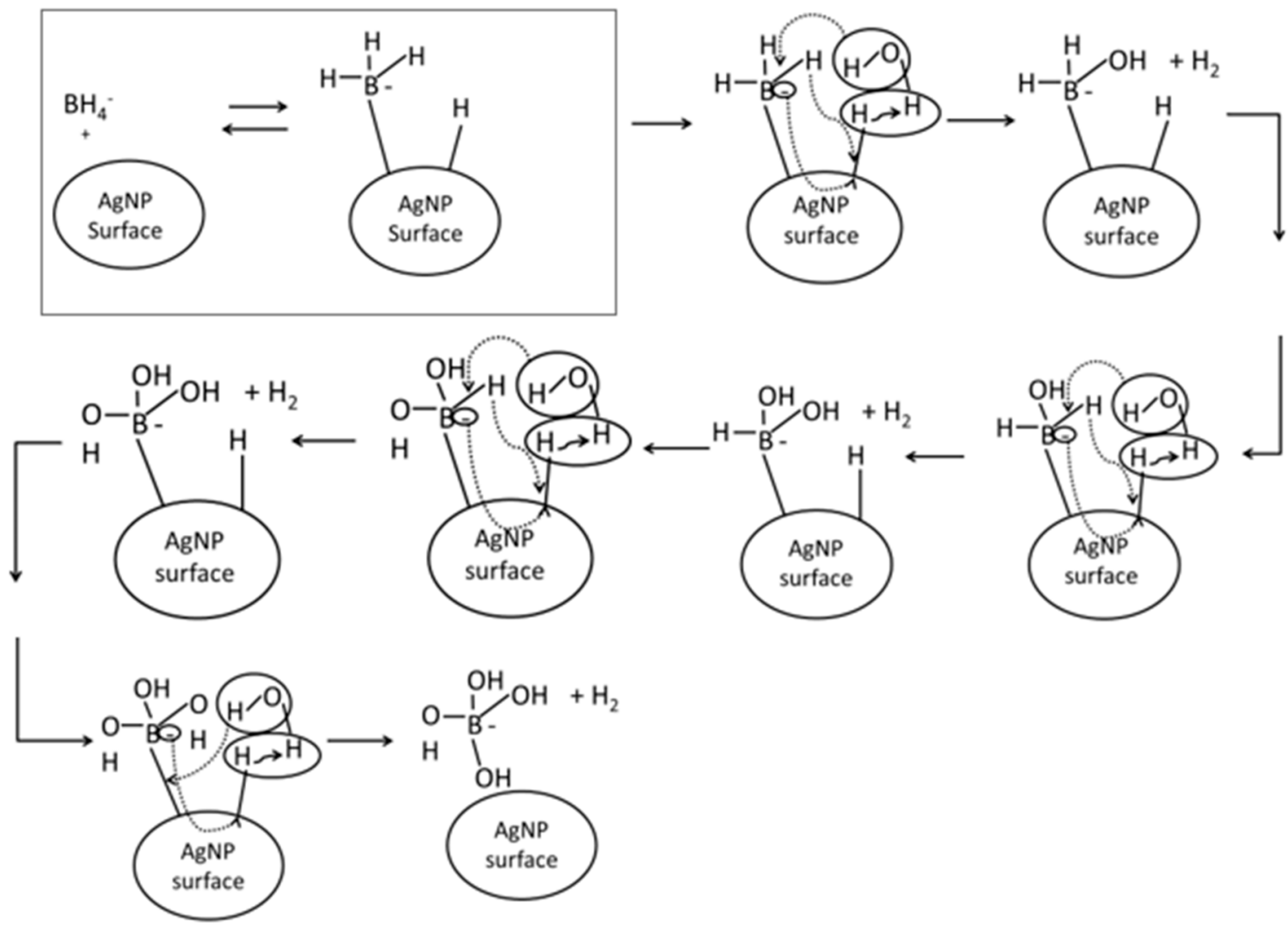

Scheme 1. Proposed mechanism of the hydrolysis of sodium borohydride, as catalyzed by the silver nanoparticle network.

\section{Materials and Methods}

\subsection{Synthesis}

Silver nitrate was used to create a $1 \mathrm{mM}$ aqueous precursor solution for the synthesis of silver nanoparticles in this experiment. The precursor solution was reduced using $250 \mu \mathrm{L}$ of a fresh aqueous solution of $180 \mathrm{mM}$ sodium borohydride $\left(\mathrm{NaBH}_{4}\right)$ in the presence of the capping agent beta-cyclodextrin. The resulting $134.5 \mu \mathrm{M}$ silver solution was stirred for two hours to facilitate the formation of silver nanoparticles. The $200 \mu \mathrm{L}$ aliquots of the resulting solution were used for catalytic activity measurements. All materials were purchased from Sigma Aldrich with high purity, unless otherwise specified.

\subsection{Characterization}

Transmission electron microscopy (TEM) confirmed the presence of silver nanoparticles in the sample. TEM further revealed the size, shape and network of the particles.

Ultraviolet-visible spectroscopy further confirmed the successful synthesis of silver nanoparticles. Nanoparticle solutions were characterized in quartz cuvettes using a Shimadzu UV-2600 UV-VIS Spectrophotometer.

\subsection{Catalysis}

A gravimetric water displacement system was used to measure the amount of hydrogen generated by the hydrolysis reaction of sodium borohydride and water in the presence of the silver nanoparticle network (AgNPN) catalyst $[11,15,19]$. The system consisted of a sealed reaction chamber, which vented into a reservoir vessel. The reservoir vessel would then displace its liquid into a third container placed on a microbalance which recorded data every $3 \mathrm{~s}$ using data-logging software. The reaction was 
conducted at various $\mathrm{pH}(6-8)$, amounts of reactant $(6.35,8.35$, and $10.35 \mu \mathrm{mol})$, and temperatures $\left(0,22\right.$, and $\left.30{ }^{\circ} \mathrm{C}\right)$. The change in $\mathrm{pH}$ was obtained using $\mathrm{HCl}$ and $\mathrm{NaOH}$ buffer solutions, while temperature was varied using hot and ice water baths. Standard reactions took place in $100 \mathrm{~mL}$ of deionized water with a concentration of $8.35 \times 10^{-4} \mathrm{NaBH}_{4}$ at room temperature $\left(20-22^{\circ} \mathrm{C}\right)$.

\section{Conclusions}

The silver nanoparticle network produced via controlled reduction was applied as a catalyst in the hydrolysis reaction of sodium borohydride. Beta-cyclodextrin was used as a capping agent for the synthesis of the nanoparticles resulting in round, fairly uniform-shaped particles. The particles functioned well as catalysts, effectively increasing the rate of the hydrogen generation reaction to as much as $18.967 \mathrm{~mL} \cdot \mathrm{min}^{-1} \cdot \mathrm{mL}_{\mathrm{cat}}{ }^{-1}$ at an increased concentration of $\mathrm{NaBH}_{4}$ at room temperature $\left(22^{\circ} \mathrm{C}\right)$. The activation energy of the reaction was $50.3 \mathrm{~kJ} / \mathrm{mol}$, which compares favorably with known literature values for hydrolysis catalysts. Sodium borohydride is an attractive hydrogen feedstock for portable fuel cell applications due to its high specific hydrogen capacity $(10.4 \mathrm{wt} \%)$ and low environmental toxicity. Silver nanoparticles have shown promise as a useful catalytic material for the generation of hydrogen gas for application in a fuel cell system, and further investigation of capping agents and nanoparticle networks can further optimize their performance.

Author Contributions: Conceptualization, T.M.A.-F.; methodology, C.H. and J.M.L.; validation, C.H., J.M.L. and T.M.A.-F.; formal analysis, C.H. and T.M.A.-F.; investigation, resources, and supervision, T.M.A.-F.; data curation, C.H.; writing — original draft, C.H. and J.M.L.; writing-reviewing, editing, and final revisions, C.H. and T.M.A.-F. All authors have read and agreed to the published version of the manuscript.

Funding: This research received no external funding.

Acknowledgments: The corresponding author acknowledges Lawrence J. Sacks' professorship in chemistry.

Conflicts of Interest: The authors declare no conflict of interest.

\section{References}

1. Dunn, S. Hydrogen futures: Toward a sustainable energy system. Int. J. Hydrog. Energy 2002, 27, 235-264. [CrossRef]

2. Haryanto, A.; Fernando, S.; Murali, N.; Adhikari, S. Current Status of Hydrogen Production Techniques by Steam Reforming of Ethanol: A Review. Energy Fuels 2005, 19, 2098-2106. [CrossRef]

3. Navarro, R.M.; Pena, M.A.; Fierro, J.L.G. Hydrogen Production Reactions from Carbon Feedstocks: Fossil Fuels and Biomass. Chem. Rev. 2007, 107, 3952-3991. [CrossRef] [PubMed]

4. Chandra, M.; Xu, Q. A high-performance hydrogen generation system: Transition metal-catalyzed dissociation and hydrolysis of ammonia-borane. J. Power Sources 2006, 156, 190-194. [CrossRef]

5. Liu, B.H.; Li, Z.P. A review: Hydrogen generation from borohydride hydrolysis reaction. J. Power Sources 2009, 187, 527-534. [CrossRef]

6. Kojima, Y.; Suzuki, K.I.; Fukumoto, K.; Sasaki, M.; Yamamoto, T.; Kawai, Y.; Hayashi, H. Hydrogen generation using sodium borohydride solution and metal catalyst coated on metal oxide. Int. J. Hydrog. Energy 2002, 27, 1029-1034. [CrossRef]

7. Özkar, S.; Zahmakıran, M. Hydrogen generation from hydrolysis of sodium borohydride using Ru (0) nanoclusters as catalysts. J. Alloys Compd. 2005, 404, 728-731. [CrossRef]

8. Schlesinger, H.I.; Brown, H.C.; Finholt, A.E.; Gilbreath, J.R.; Hoekstra, H.R.; Hyde, E.K. Sodium Borohydride, Its Hydrolysis and its Use as a Reducing Agent and in the Generation of Hydrogen. J. Am. Chem. Soc. 1953, 75, 215-219. [CrossRef]

9. Abdel-Fattah, T.M.; Wixtrom, A.; Zhang, K.; Cao, W.; Baumgart, H. Highly Uniform Self-Assembled Gold Nanoparticles over High Surface Area Dense ZnO Nanorod Arrays as Novel Surface Catalysts. ECS J. Solid State Sci. Technol. 2014, 3, M61-M64. [CrossRef]

10. Huff, C.; Dushatinski, T.; Barzanji, A.; Abdel-Fattah, N.; Barzanji, K.; Abdel-Fattah, T.M. Pretreatment of gold nanoparticle multi-walled carbon nanotube composites for catalytic activity toward hydrogen generation reactions. ECS J. Solid State Sci. Technol. 2017, 7, M69-M71. [CrossRef] 
11. Huff, C.; Dushatinski, T.; Abdel-Fattah, T.M. Gold nanoparticle/multi-walled carbon nanotube composite as novel catalyst for hydrogen evolution reactions. Int. J. Hydrog. Energy 2017, 42, 18985-18990. [CrossRef]

12. Abdel-Fattah, T.M.; Wixtrom, A. Catalytic Reduction of 4-Nitrophenol Using Gold Nanoparticles Supported on Carbon Nanotubes. ECS J. Solid State Sci. Technol. 2014, 3, M18-M20. [CrossRef]

13. Zahmakiran, M.; Ozkar, S. Zeolite-confined ruthenium (0) nanoclusters catalyst: Record catalytic activity, reusability, and lifetime in hydrogen generation from hydrolysis of sodium borohydride. Langmuir 2009, 27, 2667-2678. [CrossRef] [PubMed]

14. Patel, N.; Fernandes, R.; Miotello, A. Hydrogen generation by hydrolysis of $\mathrm{NaBH}_{4}$ with efficient Co-P-B catalyst: A kinetic study. J. Power Sources 2009, 188, 411-420. [CrossRef]

15. Huff, C.; Long, J.M.; Aboulatta, A.; Heyman, A.; Abdel-Fattah, T.M. Silver Nanoparticle/Multi-Walled Carbon Nanotube Composite as Catalyst for Hydrogen Production. ECS J. Solid State Sci. Technol. 2017, 6, 115-118. [CrossRef]

16. Zhao, Y.; Tang, Y.; Chen, Y.; Star, A. Corking Carbon Nanotube Cups with Gold Nanoparticles. ACS Nano 2012, 6, 6912-6921. [CrossRef]

17. Kochkar, H.; Aouine, M.; Ghorbel, A.; Berhault, G. Shape-Controlled Synthesis of Silver and Palladium Nanoparticles Using $\beta$-Cyclodextrin. J. Phys. Chem. C 2011, 115, 11364-11373. [CrossRef]

18. Jiang, Z.J.; Liu, C.Y.; Sun, L.W. Catalytic properties of Silver Nanoparticles Supported on Silica Spheres. J. Phys. Chem. B 2005, 109, 1730-1735. [CrossRef]

19. Huff, C.; Long, J.M.; Heyman, A.; Abdel-Fattah, T.M. Palladium Nanoparticle Multiwalled Carbon Nanotube Composite as Catalyst for Hydrogen Production by the Hydrolysis of Sodium Borohydride. ACS Appl. Energy Mater. 2018, 1, 4635-4640. [CrossRef]

20. Metin, O.; Ozkar, S. Hydrogen Generation from the Hydrolysis of Ammonia-Borane and Sodium Borohydride by Using Water-Soluble Polymer-Stabilized Cobalt (0) Nanoclusters. Catalyst. Energy Fuels 2009, 23, 3517-3526. [CrossRef]

21. Zahmakıran, M.; Özkar, S. Water dispersible acetate stabilized ruthenium (0) nanoclusters as catalyst for hydrogen generation reaction of sodium borohydride. J. Mol. Catal. A Chem. 2006, 258, 95-103. [CrossRef]

22. Metin, Ö.; Özkar, S. Hydrogen generation from the hydrolysis of sodium borohydride by using water dispersible, hydrogen phosphate-stabilized nickel (0) nanoclusters as catalyst. Int. J. Hydrog. Energy 2007, 32, 1707-1715. [CrossRef]

23. Yılmaz, M.S.; Figen, A.K.; Pişkin, S. Production of sodium metaborate tetrahydrate $(\mathrm{NaB}(\mathrm{OH}) 4 \cdot 2 \mathrm{H} 2 \mathrm{O})$ using ultrasonic irradiation. Powder Technol. 2012, 215, 166-173. [CrossRef]

24. Pena-Alonso, R.; Sicurelli, A.; Callone, E.; Carturan, G.; Raj, R. A picoscale catalyst for hydrogen generation from $\mathrm{NaBH}_{4}$ for fuel cells. J. Power Sources 2007, 165, 315-323. [CrossRef]

25. Zhao, J.; Ma, H.; Chen, J. Improved hydrogen generation for alkaline solution using carbon-supported Co-B as catalysts. Int. J. Hydrog. Energy 2007, 32, 4711-4716. [CrossRef]

26. Bindhu, M.R.; Umadevi, M. Antibacterial and catalytic activities of green synthesized silver nanoparticles. Spectrochim. Acta Part A Mol. Biomol. Spectrosc. 2015, 135, 373-378. [CrossRef] [PubMed]

27. Vidhu, V.K.; Philip, D. Catalytic degradation of organic dyes using biosynthesized silver. Micron 2014, 56, 54-62. [CrossRef]

28. Merga, G.; Wilson, R.; Lynn, G.; Milosavljevic, B.H.; Meisel, D. Redox Catalysis on "Naked" Silver Nanoparticles. J. Phys. Chem. C 2007, 111, 12220-12226. [CrossRef]

29. Kumar, A.; Mishra, B.; Tripathi, B.P. Polydopamine assisted synthesis of ultrafine silver nanoparticles for heterogeneous catalysis and water remediation. Nano-Struct. Nano-Objects 2020, 23, 100489. [CrossRef]

30. Qi, L.; Zhang, K.; Qin, W.; Hu, Y. Highly efficient flow-through catalytic reduction of methylene blue using silver nanoparticles functionalized cotton. Chem. Eng. J. 2020, 388, 124252. [CrossRef]

31. Khan, M.S.J.; Khan, S.B.; Kamal, T.; Asiri, A.M. Catalytic Application of Silver Nanoparticles in Chitosan Hydrogel Prepared by a Facile Method. J. Polym. Environ. 2020, 28, 962-972. [CrossRef]

32. Xu, R.; Wang, D.; Zhang, J.; Li, Y. Shape-Dependent Catlytic Activity of Silver Nanoparticles for the Oxidation of Styrene. Chem. Asian J. 2006, 1, 888-893. [CrossRef]

33. Andrieux, J.; Swierczynski, D.; Laversenne, L.; Garron, A.; Bennici, S.; Goutaudier, C.; Miele, P.; Auroux, A.; Bonnetot, B. Kinetics of hydrogen generation on $\mathrm{NaBH}_{4}$ powders using cobalt catalysts. Int. J. Hydrog. Energy 2008, 34, 938. [CrossRef] 
34. Zhang, X.; Wei, Z.; Guo, Q.; Tian, H. Progress of Nanoscience. J. Power Sources 2014, 231, 190. [CrossRef]

35. Guella, G.; Patton, B.; Miotello, A. Kinetic Features of the Platinum Catalyzed Hydrolysis of Sodium Borohydride from ${ }^{11}$ B NMR Measurements. J. Phys. Chem. C 2007, 111, 18744. [CrossRef]

(C) 2020 by the authors. Licensee MDPI, Basel, Switzerland. This article is an open access article distributed under the terms and conditions of the Creative Commons Attribution (CC BY) license (http://creativecommons.org/licenses/by/4.0/). 